\title{
Promoting Critical Literacy in the EFL Context: Implementing a Project to Young Learners
}

\author{
Isaak Papadopoulos \\ Aristotle University of Thessaloniki, Greece \\ Dr. Eleni Griva \\ University of Western Macedonia, Greece
}

\begin{abstract}
In response to the continually growing demands of this era, the society needs active members who are able to cooperate with each other and show a critical stance in what they read, see, touch, smell or come across. Thus, modern language education should aim at developing critical readers and writers. As a result, the critical literacy programs in which students are turned into active participants of their learning process and accept something after they have already remarked it, are more than necessary in the education of the 21 st century. This paper outlines the rational for and the purpose of designing and implementing a thematic pilot project aiming at developing students' critical literacy in an EFL (English as a foreign language) classroom. This pilot project was implemented to 20 Greek-speaking students of the 5th primary school class (aged 11 years old) who had been learning English for 4 four years. It was initiated with the purpose to provide insights into developing students' critical literacy skills as well as their four language skills in the foreign language. The project was carried out in 25 two hour sessions focused on the thematic area of the "Sports". This topic was selected because of the nature of the sports and their popularity among the teenagers. Moreover, sports are a 'controversial' subject/concept that students can express different opinions and examine it from different perspectives. Special emphasis was placed on the creation of an environment promoting critical thinking and critical stance. Moreover, an attempt was made for a pleasant and creative foreign language learning environment to be developed, where students actually could enhance personal and interpersonal skills. In order to estimate the feasibility of this project, we used three basic tools a) a pre- and a post- test about the language assessment, b) journals kept by the teacher/researcher throughout the intervention and c) structured interviews conducted by the researcher with students individually to record the students' different perspectives based on a text. The findings showed a significant improvement of the students' language skills in EFL, as well as their critical thinking and ability to examine a text from different perspectives.
\end{abstract}

Keywords: critical literacy, EFL classroom, pilot project, young learners, critical readers

\section{Introduction}

\subsection{Defining critical literacy}

Over the years many researches and scientists have defined critical literacy in various and different ways; however, they found a common ground on encouraging students to develop critical awareness of the text and understand socially constructed concepts. Thus, critical literacy involves accepting multiple perspectives and possibilities (Green, 2001) and contributes to students' learning to position themselves as active an reflective readers and writers. According to Freire (1970), "critical literacy views readers as active participants in the reading process and invites them to move beyond passively accepting the text's message to question, examine, or dispute the power relations that exist between readers and authors. It focuses on issues of power and promotes reflection, transformation, and action". Nevertheless, critical literacy does not necessarily involve showing a negative stance from the part of the reader or writer, but looking at an issue in different ways and suggesting possibilities for change and improvement. (Vasquez, 2004). 
Beatty (2013) suggests that critical literacy either helps students to "see" and think about the text from a different perspective or it promotes critical discussions based on reflection and resulting into action: "critical literacy is a stance, mental posture, or emotional and intellectual attitude that readers, listeners, and viewers bring to bear as they interact with texts (Luke, 2004). Furthermore, critical literacy is "a 'new basic' required in contemporary society. Being critically literate enables learners to navigate through the numerous texts available to them while questioning what the text claims and its authority. Students examine how the text aims to influence the reader, and how they can use the text to imagine other possible perspectives" (Luke, 2007).

Lewison, Flint and Van Sluys (2002) identify certain principles of critical literacy related to: a) investigating multiple perspectives, making and challenging common assumptions and values, b) examining the differences in power, reflecting on reading and writing. Furthermore, McLaughlin \& DeVoogd (2004) examined how critical literacy promotes understandings and beliefs about the power relationship between the reader and the author and highlighted the following basic principles. On the one hand, critical literacy focuses on issues of power and promotes reflection, transformation, and action, and on the problem and its complexity (see Oikonomakou \& Griva, 2014).

Considering the abovementioned viewpoints, we conclude that critical literacy presupposes a set of skills and strategies from the part of students in order to analyse critically the author's message, and to become critical consumers and users of information (McLaughlin \& DeVoogd, 2004).

\subsection{Critical literacy development in EFL context}

Despite the fact that for the last decades, the primary purpose of foreign language teaching has been to help students develop communicative skills, nowadays there is an emerging interest in encouraging students' critical language awareness in a foreign language context.

EFL (English as a Foreign Language) teaching has been more focused on directing students' attention to correct English structures and forms of the texts rather than to critically interrogate language use (Lotherington \& Jenson, 2011 in Fajardo, 2015). The language and text-genres choices are not neutral, since according to Janks (2010) texts are always informed by authorial bias. In other words, texts contain beliefs and messages that reflect the author's opinions, attitudes, biases and interpretations of reality. More time may be needed for encouraging students to analyse the way authors' choices of words and structures reveal implied ideologies (Fajardo, 2015).

The development of students' critical literacy helps students realize the social and ideological dimension of the language (Hatzisavvidis et al., 2010). In a critical literacy teaching context, the focal point is to make students realize the way people value the linguistic and the text choices through the language texts and the visual reproductions, as well as to help them construct their own perceptions of the reality (Hatzisavvidis, 2010). Students need to be encouraged to evaluate what is said and how it is said in the foreign language $(\mathrm{FL})$ in order to 'uncover' ideas, to disagree, and reconstruct textual representations in a FL (see also Gainer, 2010 ). Also, students need to be trained to direct and reflect on their own learning process, collaborate with others, and develop ways of handling/managing complex issues that require different kinds of expertise and critical stance (Murnane \& Levy, 1996). Besides, every student, having a different background knowledge, 'brings' to school different experiences, perspectives and ideologies. This diversity and multiplicity can facilitate the class teacher to cultivate students' respect for the diverse views and diverse way of thinking and interpreting, as well as to enhance students' ability to question, examine and explore multiple perspectives, which is the basic purpose of critical literacy.

Modern EFL practices should not be limited in enhancing students' four language skills (reading, writing, listening and speaking), but aim at developing a variety of critical awareness skills and reasoning abilities, such as examining authors' intentions and viewpoints, questioning, juxtaposing, reconstructing and exploring multiple perspectives. All these skills could be enhanced within multimodal learning environment and a task based context, by engaging students in problem solving activities such as debates, role-plays, simulations, raising critical questions, rewriting texts from another perspective ( see also Haydey, Kostiuk, \& Phillips, 2007; Morgan \& York, 2009).

In a multimodal context, students are provided with opportunities to a) take into account how linguistic choices and visual modes fulfill the purposes of a text, b) understand the different ways of meaning-making, select from various meaning- 
making modes/resources conveying certain/diverse stances, c) articulate their views and d) design multimodal texts in the target language (eg, advertisements, posters, web-pages) (see Archer, 2011; Jewitt \& Kress, 2003). Also, the advent of multimodal texts in class motivate students and enhance their positive attitude towards the target language (Korosidou \& Griva, 2014).

Furthermore, in a task-based framework, reading critically a text in a FL constitutes an interactive and intragroup and intergroup cooperative process resulting into the 'production' of various and different meanings from the part of the members of group/groups. Students communicate and collaborate with each other, so that they can effectively interact in real-life situations, communicate and construct meaning/s (Stambler, 2013). In simple words, students are enabled to use and develop their four language skills along with critical awareness, reflective and evaluation skills (Stambler, 2013). Within this environment, they practice their evaluation skills, since they always need to evaluate their classmates' stances, conclusions, perceptions and possible explanations. Students from each group are invited to present their analysis and defend their interpretation of the text to the class.

\section{The Project "'see' Sports from Different Perspectives"}

\subsection{Rationale and objectives of the project}

Having considered the impact of critical literacy programs on students' critical awareness development (eg. Hatzisavvidis, 2010; Stabler, 2013; Christensen, 1999), we decided to design and implement a pilot project on the subject of "Sports" with the purpose to develop both students' critical literacy skills and their skills in EFL. As previously mentioned, experts underline the fact that although there has recently been launched a wide range of critical literacy programmes in students' mother tongue, there has been a small number of critical literacy programmes in a foreign language (Ko \& Wang, 2009; Ko, 2013; Norton \& Toohey, 2004). As a result, the implementation of a critical literacy programme in a foreign language context was a challenge for us, aiming at:

- Developing students' critical awareness skills and EFL skills by being exposed into authentic material and engaging them into reading critically a number of multimodal texts about sports.

- Measuring the feasibility of the programme in matters of equipping students with a critical stance to reading texts about sports in their everyday life.

\subsection{Sample}

The sample consisted of 20 primary school students, who had been attending the sixth grade of a Greek primary school in Larissa (a city in Central Greece). They had been learning English as a foreign language (EFL) for four year, they were placed in the B1 level of the CEFR (Common European Framework of Reference) and they took part in this four -month programme (October - December 2014) with the permission of their parents.

\subsection{Design of the project}

\subsubsection{Module: The two 'sides' of sports}

For the purpose of the programme, a topic-based mini syllabus was designed incorporating a variety of activities that engaged students in critical and inquiry-based processes. In this framework, the expected learning outcomes involved the students' enhancement of:

Language skills, by using the target language as a medium of communication in various and authentic communicative situations. Critical Awareness skills, by developing an understanding of the ideological and social dimensions of the language through reading critically various text genres related to 'sports'. The students were expected to: a) develop strategies for critical thinking, b) be able to analyze, interpret and evaluate information found in various media sources, c) examine authors' intentions and viewpoints, d) question, juxtapose and familiarize themselves with the process of recording notes of different genres. Social skills, by enabling students to work together, interact and listen to other mates' views.

The main reason for having chosen the topic of 'sports' was that critical literacy programs should be based on themes that both teachers and students agree to deal with (Markee, 1997). Thus, the topic of 'sports' is really preferable due to its popularity among the teenagers, and is a controversial subject that students can express different viewpoints about and examine it from different perspectives. The thematic units were the following: 


\section{Thematic Unit: Definition of the concept of 'Sports'}

The aim of the first thematic unit was to introduce students to the definition of the concept of 'sports' and the 'identification' of the types of sports, as well as to encourage them express their viewpoints on related articles, visual representations, dictionaries, etc. More specifically, the students got familiarised with different types of sports within a multimodal learning environment. They raised their awareness about team and individual sports, they expressed their opinions and their ideas about the advantages and disadvantages of each sport-category and they dealt with specific vocabulary in relation to sports such as "activities", "physical activities", "outdoor sports", "indoor sports", "pitch", "field", "court", "player", "athlete", "championship" etc. They had the opportunity to compare these words with each other and be led to connections, contrasts and analogies promoting their critical thinking and developing their perceptive and productive language skills in the target language.

\section{Thematic Unit: Sports and Free time}

In this thematic unit, an attempt was made to encourage students develop their four language skills, and practice 'simple present' as a tense used to talk about hobbies, habits and general truth, as well as 'present continuous' as a tense used to talk about a current status or annoyance.

Also, students were encouraged to focus and criticise sports-matches through videos or extracts of football matches or news from British and American Channels that reported on athletes and champions who got caught up in medical doping tests. Nevertheless, students had the opportunity to: a) "read" articles about the benefits of regular activity and exercise may be beneficial for people's physical condition, b) "listen" to interviews in English from famous athletes, doctors, physical education teachers, coaches that promote sports as a free time activity, c) reflect on those articles and interviews, try to interpret and evaluate information and examine it from different perspectives, and d) debate on the role of sports in every individual's free time in order to maintain their physical and mental condition and health in contrast to the inappropriate substances that many athletes get, in order to improve their performances and strengthen their muscular system.

Special attention was placed to the inappropriate language used during several sports events by the fans and athletes and they tend to be used continually by young children as a result of their incapability to distinguish between what it right or not.

\section{Thematic Unit: Role Models}

The aim of this thematic unit was to familiarize students with important personalities of sports (major athletes) and motivate them to read about their actions. A variety of articles were incorporated with the purpose to make students comment on their behavior, their charity activities and compare those athletes with athletes who were involved in incidents of illegal substances use or of violent behaviors. Furthermore, students could also discuss on the tendency of advertise producers to invite these athletes to lead on the advertisements promoting sports clothes, equipments or even electronic devices.

Therefore, apart from dealing critically with the above mentioned facts, the students familiarised themselves with certain vocabulary in the target language such as: "I'm interested in", "I'm keen on", "I'm into", "I enjoy", "I used to", "had the habit of", "advertisements", "materialism", "products", "persuasive", role-model", "charity", "volunteer" "imitate", etc. Moreover, the students were offered the opportunity, through the athletes' biographies, to practice the past simple tense and the present perfect simple as tenses focusing on past actions. Also, they were encouraged to practice writing in the genre of mini biography with reference both to a person's hobbies and to some of his/her past actions.

\section{Thematic Unit: Values}

This thematic unit aimed at making the students discover 'values' related to an individual's participation in a sport, such as 'collaboration' and 'competition'. Moreover, they could argue about 'hostility' and 'antagonism' among the athletes and their fans who do not hesitate to do vandalisms, to spay graffiti on the walls and destroy properties in case of their favourite team loses a match or a race. Also, the students were encouraged to practice writing about the "description of an event" with particular emphasis on the expression of people's feelings and thoughts about the process of an athletic event.

Thus, the target vocabulary regarding the values of participating in sports and the vices was: "honesty", "boldness", "trust", "freedom", "team spirit", "modesty", "fun", "responsibility", "creativity", "collaboration", "diversity", "communication", "compassion", "accountability", "interdependence", etc// "antagonism", "arrogance", "hostility", "individualism", "overambition", etc. Also, the target vocabulary in relation to the feelings included the following: "happy", "sad", "mad", "brave", 
"embarrassed", "friendly", "sorry", "disappointed", "frustrated", 'silly", 'hopeful", "left out", "excited", 'jealous", "curious", "cranky", "sensitive", "insecure", "grateful", "guilty", "shy", "uncomfortable", 'hurt", surprised", 'scared", etc...

\section{Thematic Unit: Sports Facilities}

This thematic unit was designed with the purpose to engage students in activities of comparing and contradicting the sports facilities in Greece, as they were during the Olympic Games 2004, when the government provided funding for the establishments and their maintenance, with their current situation. Articles, videos, and photos of the Greek sports facilities were included. We incorporated material of the later phase, such as articles and reports referring to the abandoned stadiums that have been merely damaged and they are not used anymore as they are not available for the Greek athletes and championships.

Moreover, we included articles and photos regarding the sports facilities of other countries that have hosted the Olympic Games and they are still in use for the athletes, championships or even for charitable organisations who support people in need. Students have the opportunity to get involved in the process of comparing the foreign stadiums and their situation with the Greek ones underlining the emphasis that each country places on sports and sports facilities.

Therefore, the target vocabulary in relation to the feelings included the following: "sports facilities", "state funding", "exercising", "abandoned", "building infrastructure", "property", "neglect", "decay", "economic failure", "state negligence" while they focused on the types of sports facilities such as " a swimming pool", "a basketball court", "a badminton court", "a tennis court", "a squash court", "a volleyball court", "a football field", "a baseball field", "a hockey field", "an athletics field", "a running track", "a cycling track", "a golf course", "a golf driving range", "an archery range", "a shooting range", "a shooting gallery", etc.

\subsection{Implementation of the project}

The project was carried out in 25 three hour sessions with special emphasis on the creation of a multimodal environment, where students had the chance to come into contact with various genres, and to reflect on and discuss about controversial matters on 'sports' in a collaborative, interactive, and communicative environment. Advertisements, videos, letters/emails, stories and newspaper articles, narratives and blog-entries were some of the genres used during the intervention. The implementation stages were the following:

\subsubsection{Pre-stage}

The focus of the pre-stage was on activating students' background knowledge and motivating them by introducing the text, and setting a purpose for reading. The texts that were chosen and used by the teacher were mostly multimodal. It was during this stage that the students were prepared to cope with the demands of each one of the tasks presented to them within the modules (see also Griva \& Chostelidou, in press 2017), but were also equipped with all skills considered essential to deal with the specific topic.

\subsubsection{Task-circle}

During the while-stage, the students were provided with opportunities of working in groups, cooperating, communicating and interacting in the target language (EFL) with their classmates within group and with other groups.

In groups, the students worked on authentic materials and various genres trying to explore in depth the meaning(s) of the text, and examine the topic of sports from different perspectives. They were engaged in many tasks that promoted reflection and discussion, making decisions, thinking critically, articulating and defending their views and co-deciding on issues related to sports.

\section{Task: Approaching critically in pairs}

Description: In pairs, the students read a part of the text. After reading each part, they paused, they reflected on this part of the text, they identified the meaning, they articulated their view and exchanged ideas about this part of the text. They also made their own predictions about the following paragraph. The reading process goes on in this way.

Linguistic Objectives: This particular activity was chosen as it offers the chance to the students to read and listen to authentic linguistic input from newspapers, television channels and radio programs that helped them develop their EFL skills. 
Students were familiarised with a range of specific vocabulary, while they had the opportunity to enhance their grammatical and structural resources. While reading, students looked their unknown words up, they kept notes, they created idea-maps, hence, they practiced their four language skills.

Critical Awareness Objectives: Regarding the students' critical awareness raising, through working in groups and collaborating with each other, they were given the opportunity to read and reflect on what they were reading, discuss and exchange ideas about each topic, as well as analyse the views of the authors of the texts. The students understood and expressed different views about the target topic, thus there was a "critical" discussion among them, while employing various communicative/persuasive strategies in order to persuade their classmates about their viewpoints. Throughout this phase, students realised and developed connections between their personal views and those of their classmates concerning the topic 'under investigation', and seemed to become fully aware of a topic expanding the 'border of their personal understanding'.

\section{Task: Experiencing Mapping in groups}

The students, cooperating in groups, were reading multimodal texts and created various maps based on their personal experiences and the prompts given by the teacher. Among the prompts were used to help the students connect their experiences with the text were: "It reminds me of...", "An experience I have had like that...".

Then, they explained their connections, and the students of each group shared their mappings with their classmates of other groups, so that they could come in touch with the different perspectives and experiences of their classmates.

Linguistic Objectives: While reading the specific texts, the students were helped to pause at some points that were related to their experiences. After having completed their mappings based on their experiences, the students shared their papers with their experience-maps with their classmates and they created extra maps in cooperation. In this way, the students worked on authentic material by cooperating, interacting and exchanging experiences in the target language.

Critical Awareness Objectives: Through students' attempt to link their experiences with the text given, students managed to create a map of their personal experiences connected with the ideas of an author. Then, the students shared their maps with each other and they came across different views and experiences from different "authors".

They learnt to appreciate diverse views, the multidimensional nature of language and the power of language to develop social realities. Although many students read the same text and they were given the same prompts, they finally realised that every person interprets what he reads based on his/her own experiences and beliefs.

A special example is a picture that accompanied an article about the role of sports in our life, showing a foot ball and a vaccine 'approaching' it.

Using the prompts of "This picture reminds me of...", the students expressed various views. There were students that stated that: "it is a football and a vaccine of a doctor that tries to help the footballers when they feel sick", there were other views such as: "of course this photo is about the drugs that many athletes get to improve their performances ....", "it is a picture that shows a vaccine to approach the football, but it is not able to give drugs to the football because sports and athletes exercise and they are strong"...." "...this pictures shows us that if we do gymnastics and play many sports we will be strong and we will not have problems".

The students realised that the picture was produced with a very specific image and target in the designer's mind, but they also appreciated the multidimensional analysis created by their classmates.

\section{Task: Reflecting on a multimodal text in groups}

Students, in groups, watch and "read" a video. The students of each group stopped at certain points of the video recording, selected by the teacher, to reflect on that part and discussed with the mates of the group about what they watched, they commented on an action, an event, a situation etc and exchanged ideas, while the 'secretary' of the group was keeping notes. The students prepared a written report including their ideas about the multimodal text. Afterwards, the leader of each group announced their decision to the teacher and the classmates.

Linguistic Objectives: Being engaged in this activity, students not only developed both their receptive and productive skills in EFL. More precisely, a) they had the chance to participate in authentic conversations through using the target language, 
b) they had to understand the language input he/she came across in a multimodal context and then express his/her views on it, c) they had to listen carefully to the partner's opinion so that to use appropriate language devices to support their views, especially in cases of disagreement.

Critical Awareness Objectives: The students, based on their personal experience, supported their views and ideas at certain teacher-selected points. In this way, they informed their partners about a specific topic or part of the text/video they dealt with and then they were engaged in discussing about it. They appreciated the "two sides" but they tried to realise why an event or an action is presented in a particular way through the use of certain language devices that each author uses.

During the project, the students relied significantly on the Critical Literacy Questions to Ask of Texts (Yale University, 2013). Firstly the students used a set of questions related to "textual purposes". Then, they dealt with the "textual structures and features". Specifically, they were introduced to different text types and genres, while particular emphasis was placed on the images, the words and the formality of the language that the author(s) decided to use. It is worth mentioning that the students were also encouraged to express themselves and justify these particular language and imagery use.

Moreover, they used a number of questions related to the "construction of characters". In fact, the students 'investigated' how young and adults were presented, trying to focus also on the reason the writer or producer of the materials had made them act in that particular way in a text type. Apart from that, students "questioned" about the material in matters of "gaps and silences". To be specific, they tried to look into possible gaps and silences in the material and they tried to give some explanations about those absences by 'revealing' some reasons.

In relation to the texts about the "advantages of sports", according to students' views, 'sports' could benefit "gym owners who promote their services", "coaches who try to persuade young people take up sports" or even "health dieticians trying to raise people's awareness about the importance of a balance between health eating habits and regular exercise". Meanwhile, a television commercial promoting a famous footballer advertising his new trainer could benefit "the company of the trainers" but there is also a missing fact that "not only athletic trainers guarantee the success but regular trainings".

\subsubsection{Follow-up stage}

The students were invited to: a) transform their newly acquired knowledge, b) produce their own text, c) reflect on their own progress. Specifically, the students were provided with opportunities to enhance their creativity by producing their own multimodal texts in the target language (eg. passages, posters, advertisements, and videos).

\section{Evaluation of the project}

In order to evaluate the impact of this pilot implementation on critical awareness development and EFL language skills enhancement, as well as to determine whether the objectives chosen a priori were fulfilled, the researcher used three methodological tools:

\subsection{Pre and post- test}

A pre-test, focusing on the thematic area of sports, was distributed to all students before initiating this project, while a posttest was distributed to the students upon the completion of the implementation. It should be noted that both the pre and the post- test referred to the same skills, so that the results can be objective and measure the effectiveness of this particular intervention (Stocking, 1999). The test consisted of 25 multiple-choice questions related to 'sports'.

\subsubsection{Results}

The following table.1 shows the mean scores and the standard deviation of the students' correct answers in the pretest to the post- test. As it is obvious, an improvement in the students' scores of their language level at the post-test (Mean Scores: 22) has been released, compared with their performance at the pre-test (Mean Scores: 12).

Table 1. Mean scores and Std. Deviation of Pre- and Post- Test

\begin{tabular}{|l|l|l|l|}
\hline $\begin{array}{l}\text { Mean } \\
\text { (Pre-test) }\end{array}$ & $\begin{array}{l}\text { Mean } \\
\text { (Pre-test) }\end{array}$ & $\begin{array}{l}\text { Mean } \\
\text { (Pre-test) }\end{array}$ & $\begin{array}{l}\text { Mean } \\
\text { (Pre-test) }\end{array}$ \\
\hline 12 & 0,73 & 22 & 0,67 \\
\hline
\end{tabular}




\subsection{The journal of the researcher/teacher}

The teacher/researcher's journal was used, since it has been proved a very effective tool to assess experimental and educational interventions (Altrichter et al, 1993; Papadopoulos \& Griva, 2014). The researcher kept notes upon the completion of each teaching session reflecting mostly on the students' engagement into reading critically various multimodal texts. The structure of the journal was based on the "questions to guide reflection journal entries" (Richards \& Lockhart, 1994: 16 -17) as follows:

a) Questions about the instruction process

1. What objectives did I set? To what extend did I achieve them?

2. What teaching material did I use? How effective were the teaching aids?

3. What forms of communication among students and the teacher were used?

b) Questions about students' attitude and participation

Which was the students" attitude at the beginning, middle and at the end of each activity? How did I react?

c) Questions about the general estimation of the instruction.

1) What went well and what did not? Why?

2) What could I change? Why?

\subsubsection{Results}

Through the analysis of the journal entries, it was revealed that a variety of techniques, activities and aids were used in the specific teaching context. In particular, the teacher offered the students opportunities for intergroup interaction through using multimodal material encouraging them to examine and reflect on certain topics. Students came across news stories, leaflets, news articles and digital material with information about sports. It was noted that while students were communicating and interacting with each other, they shifted from mother tongue to foreign language in a natural learning process (translanguaging is used).

The students exhibited special interest in group cooperation and in language mediation activities. They were motivated to read critically and reflected on the topics of multimodal texts. Meanwhile, the teachers served as a facilitator of the learning process, by providing assistance and encouragement to students, and giving instructions for this "unknown so far" way of working and scaffolding. However, throughout this project, the students encountered some difficulties in relation to EFL use, as well as to reflect and discuss critically on a "message", mainly at the first sessions. Specifically, they faced some difficulties in understanding certain concepts in relation to sports and further in using appropriate specific vocabulary while interacting with their classmates.

Concerning the benefits gained through students' participating in the project, it was recorded that they managed: a) to develop their social skills not only through being aware of the social dimension of language, but also through their interaction with their classmates as well; b) to enhance their EFL skills and their cognitive skills; c) to develop critical awareness skills, as they were equipped with a critical stance towards 'reading and interpreting the meaning/message' of a variety of multimodal texts.

\subsection{Student Interviews}

Moreover, an interview was conducted with each student individually. Throughout the interview, the researchers attempted to investigate students' various perspectives regarding 'sports' based on the article given to them and on the Critical Literacy Questions to Ask of Texts (Yale University, 2013),

The questions were as follows:

Critical literacy questions for textual purposes 
- what is this text about? How do we know?

- who would be most likely to read and/or view this text and Why?

- why are we reading and/or viewing this text?

- what does the composer of the text want us to know?

Critical literacy questions for textual structures and features

- what sort of genre does the text belong to?

- what do the images suggest?

- what do the words suggest?

- what kind of language is used in the text?

Critical literacy questions for construction of characters

- how are children, teens, young adults constructed in the text?

- why are the characaters represented in a particular way?

Critical literacy questions for gaps and silences

- $\quad$ are there 'gaps' and 'silences' in the text?

- who is missing from the text?

- what questions about itself does the text not raise?

Critical literacy questions for power and interest

- who benefits from the text?

- is the text fair?

Whose view; whose reality?

- What view of the world is the text presenting?

- What kinds of social realities does the text present?

- What is real in the text?

Interrogating the composer

- What kind of person composed the text?

- What view of the world does the composer assume?

Multiple meanings

- What different interpretations of the text are possible?

- How else could the text have been written?

\subsubsection{Results}

At the first stage of the interviews, the students managed to identify the main idea of the text , eg. "the importance of sports in our life", "the benefits of physical exercise", but they did not get a pre-critical interpretation of the text. However, at the 
next stages of the interviews, students' stances changed, they presented multiple perspectives and aspects of the "sports" and thought critically about the texts.

Concerning the analysis of the interviews, based on the critical literacy questions, basic typologies emerged with subcategories, giving further meanings and understanding in relation to students' critical awareness.

\begin{tabular}{|c|c|}
\hline \multicolumn{2}{|c|}{ Category: Critical literacy questions for the text } \\
\hline Textual purposes & $\begin{array}{l}\text { 1. "the text focuses on the benefits of the physical exercises in a try to make people with a } \\
\text { sedentary life take up a sport" } \\
\text { 2. "this text is about the different aspects of sports in our lives as the one in competitions, or in the } \\
\text { people's everyday life or even at schools without mentioning a disadvantage because the author } \\
\text { wanted to persuade people take up a hobby" } \\
\text { 3. "this text describes only the benefits of sports in our live from a young age to an old age in an } \\
\text { attempt to motivate people from a young age to take up sports, a habit they may carry till their old } \\
\text { age }\end{array}$ \\
\hline $\begin{array}{l}\text { Textual structures } \\
\text { and features }\end{array}$ & $\begin{array}{l}\text { 1."of course this text is an article since we can see the title above it, the sources of the } \\
\text { newspaper/website and generally the form of this text is related to the articles writing" } \\
\text { 2."I can see an athlete walking on a treadmill and eating a pizza at the same time, to be honest } \\
\text { there are many thoughts and ideas about this picture, it may want to show us that there are many } \\
\text { athletes that take regular exercise but they eat also junk food in moderation" } \\
\text { 3. "it may want to show us that sports can serve as a medicine for the people because they help } \\
\text { our health and can make us to avoid fast food..." } \\
\text { 4. "as we can see the man is going to eat the pizza but he does not and that means that if we } \\
\text { stand up to the unhealthy food and the people who advertise them, we can get all the physical } \\
\text { benefits of the sports physically and emotionally because people who try to make us eat fast food } \\
\text { try to prevent people from sports, they think only about their incomes. } \\
\text { 5. "there are many repetitions of the beneficial role of sports so, we can understand that the author } \\
\text { wants to persuade people about participating in a sport"... } \\
\text { 6. "the language of the author is sometimes formal and sometimes semi-formal because he refers } \\
\text { either to children or to adults and that's why these two categories are offered different language } \\
\text { level so that the author can be understandable. }\end{array}$ \\
\hline \multicolumn{2}{|c|}{ Category: Critical literacy questions for construction of characters } \\
\hline $\begin{array}{l}\text { The way children, } \\
\text { teens are } \\
\text { constructed in the } \\
\text { text }\end{array}$ & $\begin{array}{l}\text { 1."Children are presented as the ones playing and doing sports every day and the author connects } \\
\text { this habit of children with their happiness" } \\
\text { 2."The author presents the teenagers not enjoying very much doing sports as they have much of } \\
\text { homework...the author mentions that the education system is very strict and he presents the } \\
\text { teenagers as passive people" } \\
\text { 3."The young adults are divided. There are some people who combine their responsibilities and } \\
\text { their exercise... but there is another category of people who are very pressed they don't think } \\
\text { about exercise and gymnastic" }\end{array}$ \\
\hline $\begin{array}{l}\text { The reason these } \\
\text { characters are } \\
\text { represented in a } \\
\text { particular way }\end{array}$ & $\begin{array}{l}\text { 1."Children are very happy with their games and sports, the author maybe wants to persuade us } \\
\text { that if you play and do sports from this age we will be happy and healthy. he uses the children } \\
\text { as a stimulus for all the other people" }\end{array}$ \\
\hline
\end{tabular}




\begin{tabular}{|c|c|}
\hline & $\begin{array}{l}\text { 2."Of course the teenagers do not have free time because they study a lot. The author believes } \\
\text { with this way that the education system of our country is not very good and it does not offer many } \\
\text { times of relaxing and doing sports. Students must study for the school and to go to the university } \\
\text { and their physical situation is not a necessary thing for them". } \\
\text { 3. "Some young adults manage to do sports and they are healthy and others do not do sports } \\
\text { and they have obesity problems because they work in their office very much. We know that our } \\
\text { country has many economic problems and this makes the people to work for so many hours } \\
\text {...they don't care about the sports and they eat very junk food because they hurry." }\end{array}$ \\
\hline \multicolumn{2}{|c|}{ Category: Critical literacy questions for gaps and silences } \\
\hline $\begin{array}{l}\text { Investigating } \\
\text { "gaps" and } \\
\text { "silences" }\end{array}$ & $\begin{array}{l}\text { 1."The author promotes only the benefits of exercising but he does not inform people about some } \\
\text { dangers of the sports...many athletes have health problems and injuries..." } \\
\text { 2."The voice of the athletes is missing...they live and they do gymnastics everyday and I think that } \\
\text { they do not find that sports help us to relax..." } \\
\text { 3."The author presents only the benefits of sports for people who do not do gymnastics. For } \\
\text { example, students and people who work and they do not have much free time for exercising may } \\
\text { support that sports will make them tired or they may say their opinion about the negative side of } \\
\text { sports...." }\end{array}$ \\
\hline \multicolumn{2}{|c|}{ Category: Critical literacy questions for power and interest } \\
\hline $\begin{array}{l}\text { Matters of } \\
\text { Fairness }\end{array}$ & $\begin{array}{l}\text { 1."Although at the beginning, I believed that this text is very important for all of us, I think now that } \\
\text { this text is not very informative! It is not fair! When we mention only the one side of a matter and } \\
\text { not the other, then the people cannot learn all the things" } \\
\text { 2."The author in this text helps the coaches, the gym owner and of course he does not support } \\
\text { people who are not active...it is something like bullying for people who do not do sports" } \\
\text { 3." Of course this text is not fair! It is about the advantages of sports without to mention the bad } \\
\text { things of them. When we read a text we should read all the sides...the author possibly is a } \\
\text { sportsman and he does not support the others..." }\end{array}$ \\
\hline \multicolumn{2}{|c|}{ Category: Whose view; whose reality? } \\
\hline $\begin{array}{l}\text { The view of the } \\
\text { world in the text }\end{array}$ & $\begin{array}{l}\text { 1."The text presents a world with many people who do not do sports...only the children play and } \\
\text { do gymnastics when they young, but when they get older, they stop it!" } \\
\text { 2."The text is very strange. I think that there are many advantages of sports but indirectly it shows } \\
\text { that the world has many problems and it needs sports...it presents a problematic world" } \\
\text { 3."The author presents a world of happiness for people who like sports but it also gives some } \\
\text { points for people who do not like them and it mentions that there is something wrong with people." }\end{array}$ \\
\hline $\begin{array}{l}\text { What is real in the } \\
\text { text? }\end{array}$ & $\begin{array}{l}\text { 1."We can understand that people who work do not have much time for exercising but NOT all of } \\
\text { them" } \\
\text { 2."It is real that many young people play and do sports but they do not have the jobs of their } \\
\text { parents..." } \\
\text { 3." Generally, I believe that all the things that the author says are real but he does not write about } \\
\text { their negative side.." }\end{array}$ \\
\hline
\end{tabular}




\begin{tabular}{|l|l|}
\hline Matters of Author & $\begin{array}{l}\text { 1."The author is certainly an active person..and of course a coach...his language is like a coach } \\
\text { speaking and of course he also talks about young children...maybe he is a coach of young people" } \\
\text { 2."The author is of course a gym owner.I believe that he promotes his gym and he tries to } \\
\text { persuade people with sedentary lifestyle take up sports" } \\
\text { 3."I believe that the person who wrote this text is a promoter. The text has some special } \\
\text { information about sports and I think that these people who promote vitamins, proteins and other } \\
\text { medicines write these texts to attract the people and then to make them buy their products!!!!" }\end{array}$ \\
\hline Category: Multiple meanings \\
\hline $\begin{array}{l}\text { Changed article } \\
\text { 1."The text should include both the negative and positive sides of sports...so it will be fair and it } \\
\text { 2."The text can have more information about the benefit of sports and not write certain negative } \\
\text { things about the people who do not do sports" } \\
\text { 3."The text should have more pictures about each of the categories it presents...it should have } \\
\text { more information about the ways that people who work, can take up sports because it does not } \\
\text { give solutions...it only presents the benefits ..." }\end{array}$ \\
\hline
\end{tabular}

\section{Concluding remarks}

The project "see' sports from different perspectives" was designed with the purpose to promote students' critical awareness skills and EFL skills by exposing them into authentic material (multimodal input from newspapers, television channels and radio programs) and encouraging them to examine a number of multimodal texts about sports from a critical stance. More precisely, an attempt was made for students to be equipped with the appropriate skills needed for the demands of "the media saturated, diverse world" (Comber, 2001).

The participants of the pilot project managed to deeply understand information in the area of "sports" through "coming in touch' with a variety of texts, and they realized that reading critically a text involves looking for multiple perspectives and possibilities and using literacy as an agent of social change (Green, 2001). Being engaged in this project, they were turned into active readers moving beyond passively accepting the text's message by questioning, examining or disputing the power relations between the readers and the authors. In other words, the students managed to enhance and deepen comprehension mainly through the analysis of 'how' and 'to what degree' the text promotes the status quo. They questioned, examined, or disputed the power relations between readers and authors focusing on issues of power and promoting reflection, transformation, and action (Freire, 1970).

Throughout this project, the students, having engaged in critical activities, focused on the power and the interest of various texts and they paid special attention to the view of the world and the social realities that are presented in the texts. Also, they were given the opportunity to discuss controversial matters on sports, exchange ideas about the topics in a collaborative, interactive, and communicative EFL context. Moreover, they familiarized themselves with techniques of identifying and assessing their own responses and relationships to the text. while their attempt to analyze how texts have been constructed and how they influence audiences was really advantageous. They were also able to evaluate the validity and reliability of the text and its premises serving as researchers of languages and texts (Green, 2001).

Concluding, the critical literacy implementation can be regarded as advantageous for the EFL students, since it contributed to helping them raise their critical awareness skills as well as encouraging them to realize that language is used to create particular social realities, to interpret the meaning/message of multimodal EFL texts and to express and justify their viewpoints on different text types and genres.

\section{References}

[1] Altrichter, H., Posch, P. \& Somekh, B. (1993). Teachers Investigate their Work: An Introduction to the Methods of Action Research. London / New York: Routledge. 
[2] Archer, A. (2011). Clip-art or Design: Exploring the challenges of multimodal texts for Writing Centres in Higher Education. Southern African Linguistics and Applied Language Studies 29 (4), 387-399.

[3] Christensen, L. M. (1999). Critical literacy: Teaching reading, writing, and outrage. In C. Edelsky (Ed.), Making justice our project: Teachers working towards critical whole language practice (pp. 53-67). Urbana: NCTE.

[4] Comber, B. (2001). Classroom explorations in critical literacy. In H. Fehring \& P. Green (Eds.), Critical literacy: A collection of articles from the Australian Literacy Educators' Association (pp. 90-111). Newark, Delaware: International Reading Association.

[5] Fajardo, M.F. (2015). A review of critical literacy beliefs and practices of English language learners and teachersUniversity of Sydney Papers in TESOL, 10, $29-56$.

[6] Freire, P. (1970). Pedagogy of the oppressed. New York Seabury.

[7] Gainer, J., S. (2010). Critical media literacy in middle school: Exploring the politics of representation. Journal of Adolescent \& Adult Literacy 53(5), 364-373.

[8] Green, P. (2001). Critical literacy revisited. In H. Fehring \& P. Green (Eds.), Critical literacy: A collection of articles from the Australian Literacy Educators' Association (pp. 7-13). Newark, Delaware: International Reading Association.

[9] Griva, E. \& Chostelidou, D. (in press, January 2017). CLIL in Primary Education: promoting multicultural citizenship awareness in a foreign language classroom. In E. Griva \& A. Deligianni (Eds). RPLT Special Volume on CLIL, HOU.

[10] Hatzisavvidis, S., Kostouli, T. \& Tsiplakou, S. (2010). The proposal for the language teaching: Critical literacy and new text practices at school (in Greek). Nicosia: Pedagogical Institute.

[11] Haydey, D. C., Kostiuk, J., \& Phillips, S. (2007). Developing critical literacy for all students. TalentEd 25(1), 1925.

[12] Janks, H. (2010). Literacy and Power. New York: Routledge.

[13] Jewitt, C., \& Kress, G. (2003). Multimodal literacy. New York: Peter Lang.

[14] Ko, M. (2013). A critical discourse analysis of EFL learners' post-reading reflections in a critical literacy-based class. English Linguistics Research, 2(2). http://dx.doi.org/10.5430/elr.v2n2p1.

[15] Ko, M. Y., \& Wang, T. (2009). Introducing critical literacy to EFL teaching: Three Taiwanese college teachers' conceptualization. Asian EFL Journal 11(1), 174-191.

[16] Korosidou, E. \& Griva, E. (2014). CLIL Approach in Primary Education: Learning about Byzantine Art and Culture through a Foreign Language. Studies in English Language Teaching 2(2), 216-232.

[17] Lewison, M., Flint, A. S., \& Van Sluys, K. (2002). Taking on critical literacy: The journey of newcomers and novices. Language Arts 79, 382-392.

[18] Luke, A. (2004). Foreward. In M. McLaughlin \& G. Devoogd (Eds), Critical Literacy: Enhancing students' comprehension of text. New York: Scholastic.

[19] Luke, A. (2007). Critical literacy Toronto. Literacy and Numeracy Secretariat. Available at: http://resources.curriculum.org/secretariat/november29.shtml

[20] Markee, N. (1997). Second Language Acquisition Research: A Resource for Changing Teachers' Professional Cultures. The Modern Language Journal 81(1), 80-93.

[21] McLaughlin, M., \& DeVoogd, G. (2004). Critical literacy: enhancing students' comprehensionof text. New York: Scholastic. 
[22] Morgan, H., \& York, K. C. (2009). Examining multiple perspectives with creative think-alouds. The Reading Teacher 63(4), 307-311.

[23] Murnane, R. J. \& Levy, F. (1996). Teaching the new basic skills. New York: Free Press.

[24] Norton, B., \& Toohey, K. (2004). Critical pedagogies and language learning. Cambridge University Press. http://dx.doi.org/10.1017/CBO9781139524834

[25] Oikonomakou, M. \& Griva, E. (2014). Critical Literacy in the Language Curricula of Primary Education: a comparative study. In the proceedings of the Conference Critical Literacy and Educational Practices. http://www.nured.uowm.gr/drama.

[26] Papadopoulos, I. \& Griva, E. (2014). Learning in the races of Greek Culture: a CLIL project for raising cultural awareness and developing L2 skills. International Journal of Learning, Teaching and Educational Research 8, 76-92.

[27] Richards, J. C., \& Lockhart, C. (1994). Reflective teaching in second language classrooms. Cambridge: Cambridge University Press.

[28] Stambler, L. G. (2013). Literacies for the Digital Age to teach in the K-12 classroom. Yale: Pier Institute, Yale University.

[29] Stocking, K. M. (1999). Evaluating Environmental Education. Cambridge: Commission on Education and Communication.

[30] Vasquez, V.M. (2004). Negotiating critical literacies with young children. Mahway, N.J.: Lawrence Erlbaum. 